\title{
Kidney Neoplasm
}

National Cancer Institute

\section{Source}

National Cancer Institute. Kidney Neoplasm. NCI Thesaurus. Code C3150.

A benign or malignant neoplasm affecting the kidney. Representative examples of benign renal neoplasms include fibroma, lipoma, oncocytoma, and juxtaglomerular cell tumor. Representative examples of malignant renal neoplasms include renal cell carcinoma, renal pelvis carcinoma, Wilms tumor, rhabdoid tumor, sarcoma, and lymphoma. 